\title{
A long-term survivor of metachronous liver metastases of pancreatic serous cystic neoplasm associated with von Hippel-Lindau disease
}

\author{
Takashi Kokumai', Masamichi Mizuma1 ${ }^{*} \mathbb{0}$, Katsuya Hirose², Hideaki Karasawa', Masaharu Ishida1, \\ Hideo Ohtsuka' , Kei Nakagawa', Takanori Morikawa' , Takashi Kamei ${ }^{1}$, Atsushi Masamune ${ }^{3}$ Toru Furukawa ${ }^{2}$ and \\ Michiaki Unno'
}

\begin{abstract}
Background: Pancreatic serous cystic neoplasm (SCN) is an uncommon exocrine neoplasm, which is believed to be a benign entity. However, some of these neoplasms may occasionally attain metastatic ability. Von Hippel-Lindau disease (VHL) manifests a dominantly inherited systemic syndrome accompanied by several benign or malignant tumors, including cystic tumors, in various organs. We describe here a long-term survival case who underwent surgical resection for metachronous liver metastases of pancreatic SCN associated with VHL disease.

Case presentation: A 35-year-old woman with VHL underwent total pancreatectomy and right nephrectomy for pancreatic SCN and renal cell carcinoma, respectively. At the 4th year follow-up examination after the resection, contrast-enhanced computed tomography $(\mathrm{CT})$ and gadolinium ethoxybenzyl diethylenetriamine penta-acetic acid (Gd-EOB-DTPA)-enhanced magnetic resonance imaging (MRI) showed arterially hyper-enhanced neoplastic lesions in the segment VI and VIII of the liver. Partial resections of the liver were performed 53 months after the initial surgery. At the 6th month follow-up examination from the second surgery, one and two tumors located in the liver segment III, and VIII, respectively, were detected by contrast-enhanced CT and Gd-EOB-DTPA-enhanced MRI. Anterior segmentectomy and partial resection of the segment III were performed 66 months after the initial surgery and 13 months after the second, respectively. The tumors were pathologically diagnosed as liver metastases of pancreatic SCN synonymous with serous cystadenocarcinoma. She remains disease-free without recurrence 6.5 years after the last operation.

Conclusions: This is the first report of a case of metastatic SCN associated with VHL. Surgical resection might confer a favorable prognosis in patients of pancreatic SCN with liver metastases.
\end{abstract}

Keywords: Serous cystadenocarcinoma, Serous cystic neoplasm, Von Hippel-Lindau disease, Metastasis

\section{Background}

Pancreatic serous cystic neoplasm (SCN) is an uncommon tumor that accounts for $1-2 \%$ of exocrine neoplasms of the pancreas [1]. SCN, which is generally considered to be benign, is very rarely malignant. In 1989, George et al. reported the first autopsy case of malignant

\footnotetext{
*Correspondence: masamichi@surg.med.tohoku.ac.jp

${ }^{1}$ Department of Surgery, Tohoku University Graduate School of Medicine,

1-1 Seiryomachi, Aobaku, Sendai 980-8574, Japan

Full list of author information is available at the end of the article
}

SCN of the pancreas metastasizing to the stomach and liver [2]. Since then several cases of malignant SCN have been reported. The actual proportion of malignancy in pancreatic SCNs has been reported to be only $0.6 \%$ [3].

Von Hippel-Lindau disease (VHL) is an autosomal dominant neoplasia syndrome that results from germline mutations in the $V H L$ genes $[4,5]$. These mutations lead to the development of several benign or malignant 

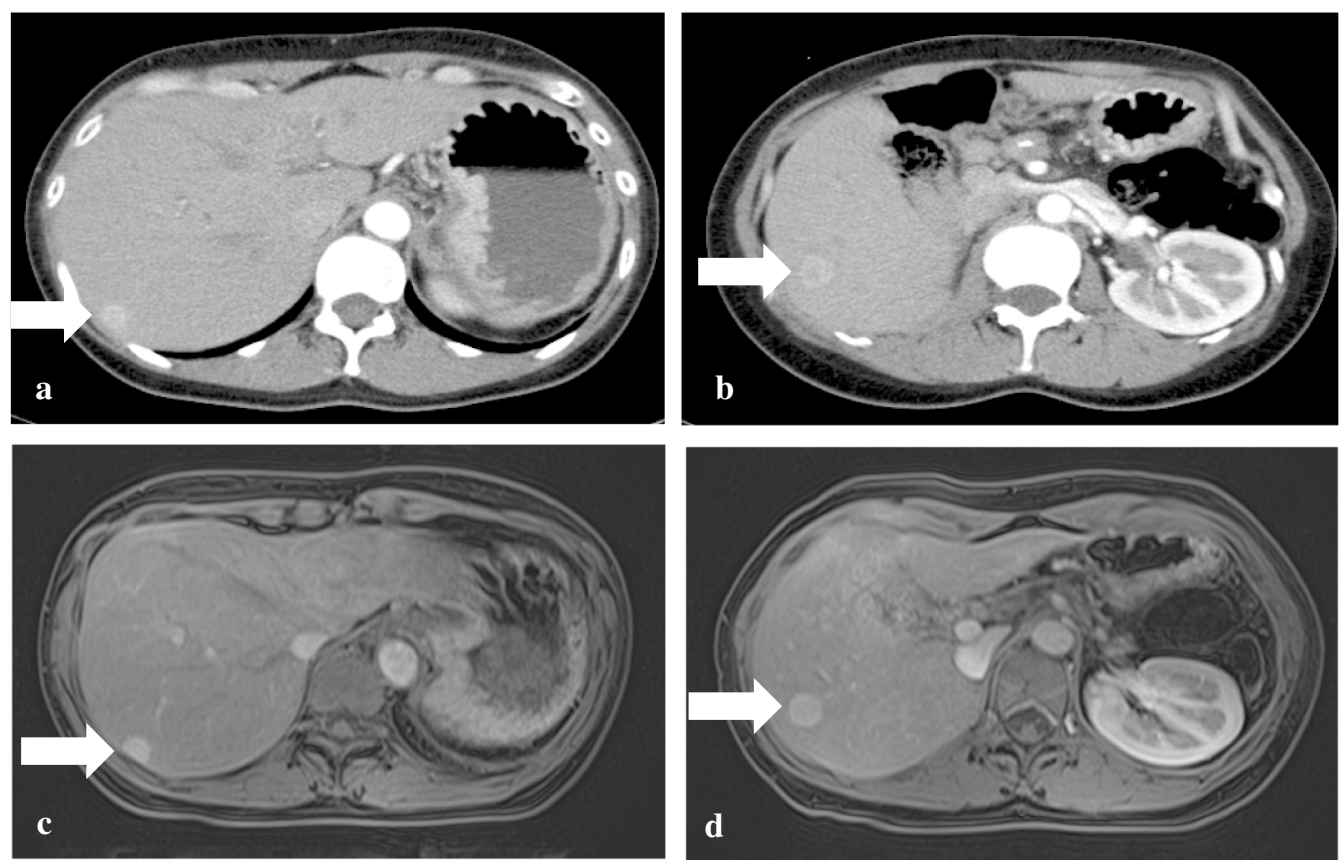

Fig. 1 a, b Contrast-enhanced CT showed arterially hyper-enhanced lesions in liver segment VIII (a, arrow) and VI (b, arrow). c, d Gd-EOB-DTPA-enhanced MRI showed arterially hyper-enhanced lesions in liver segment VIII (c, arrow) and VI (d, arrow). CT computed tomography, Gd-EOB-DTPA gadolinium ethoxybenzyl diethylenetriamine penta-acetic acid, MRI magnetic resonance imaging

tumors, including cystic tumors, in various organs. Pancreatic SCNs associated with VHL were found in $9-11 \%$ of patients $[6,7]$. However, no cases of malignant SCN associated with VHL have ever been reported.

We previously reported a case of VHL with a germline $V H L$ mutation, $233 \mathrm{~A}>\mathrm{T}$, who underwent total pancreatectomy for multiple SCNs and right nephrectomy for renal cell carcinoma [8]. Herein, we report that this case developed multiple metachronous liver metastases of the SCN after the initial operation and underwent surgical resections for the metastases. This patient has been alive without any recurrence more than 6 years after the metastasectomies.

\section{Case presentation}

A 35-year-old woman with VHL who underwent total pancreatectomy and right nephrectomy for pancreatic SCN and renal cell carcinoma (RCC), respectively, had postoperative follow-up examinations performed every 6 months [8]. At the 4th year follow-up examination, $12-\mathrm{mm}$ and $15-\mathrm{mm}$ tumors in the liver segment VIII and VI, respectively, were detected as hyper-enhanced mass in the early phase by contrast-enhanced computed tomography (CT) scan (Fig. 1a, b). Gadolinium ethoxybenzyl diethylenetriamine penta-acetic acid (Gd-EOB-DTPA)-enhanced magnetic resonance imaging (MRI) revealed arterially hyper-enhanced lesions in the liver, which were the same as the findings of the CT scan (Fig. 1c, d), showing iso-enhancement in the portal phase and hypo-enhancement in the delayed phase compared with the liver parenchyma. The liver tumors were radiographically diagnosed as metachronous metastases of pancreatic SCN or RCC. Partial resections of the liver were performed 53 months after the initial surgery. Contrast-enhanced intraoperative ultrasonography (CEIOUS) using Sonazoid (gaseous perflubutane) showed early enhanced hyperechoic tumors in the liver, whereas intraoperative indocyanine green (ICG) fluorography showed no liver tumor. In the intraoperative macroscopic findings, the liver tumors were obscure. In microscopical observations, the tumors were confined in portal regions without invasion into the hepatic parenchyma, which consisted of microcysts lined by cuboidal epithelial cells with clear cytoplasm containing large amounts

(see figure on next page.)

Fig. 2 a Microscopic features of the primary renal cell carcinoma (RCC) and pancreatic serous cystic neoplasm (PSCN), and metachronous metastatic liver tumors (first LM and second LM). The metastatic liver tumors showed multiple microcysts consisting of cuboidal cells with clear cytoplasm in the portal regions. No involvement of the liver parenchyma was noted (hematoxylin and eosin stain, $\times 200$ ). $\mathbf{b}-\mathbf{e}$ Immunohistochemical analysis of CK7 (b), EGFR (c), inhibin a (d), and PAX8 (e) showed that PSCN and metastatic tumors (first LM and second LM) showed the same expression phenotypes that were different from those of RCC $(\times 200$ in original magnifications) 

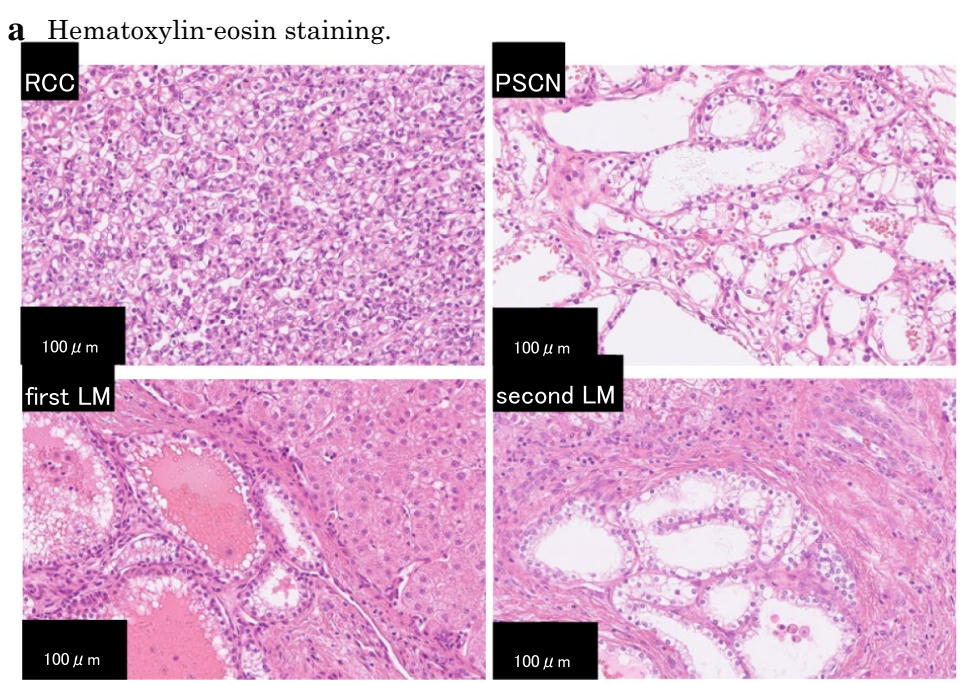

\section{b $\quad$ CK 7}
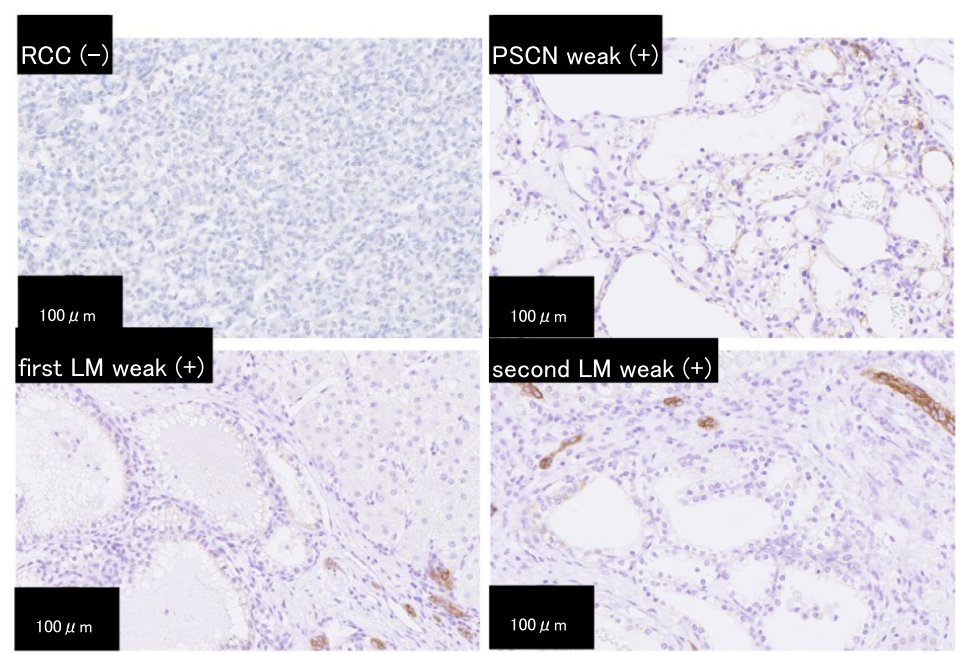

c EGFR

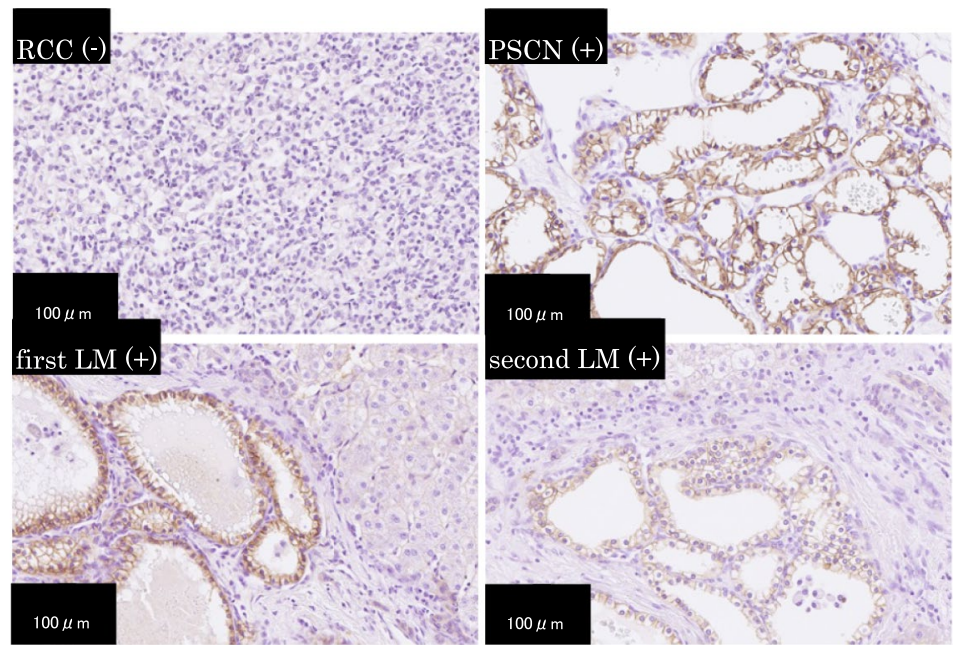



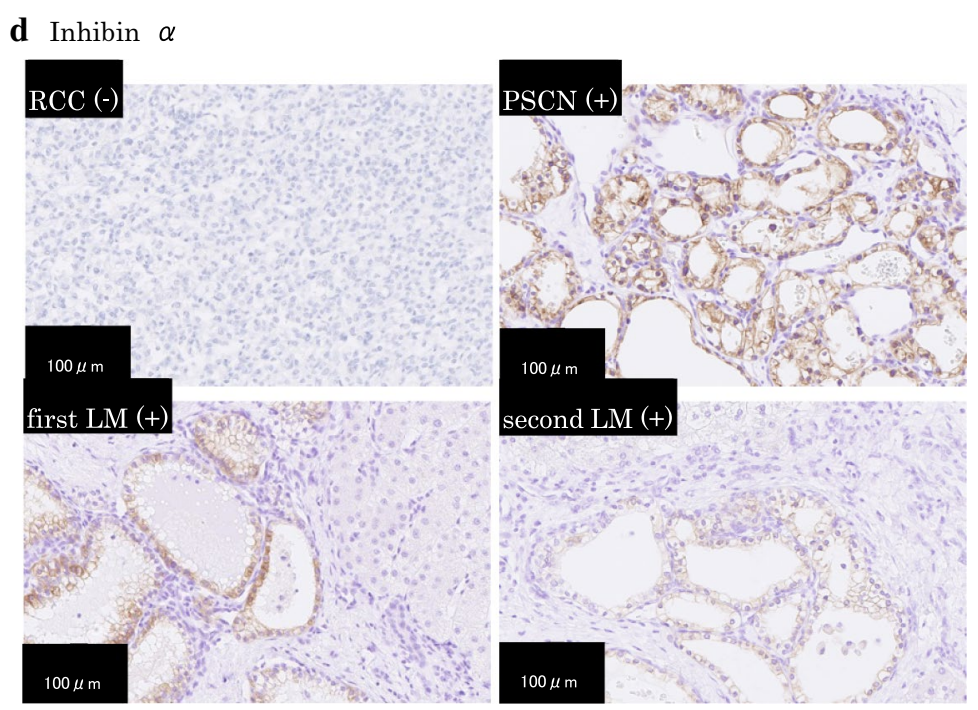

e PAX8
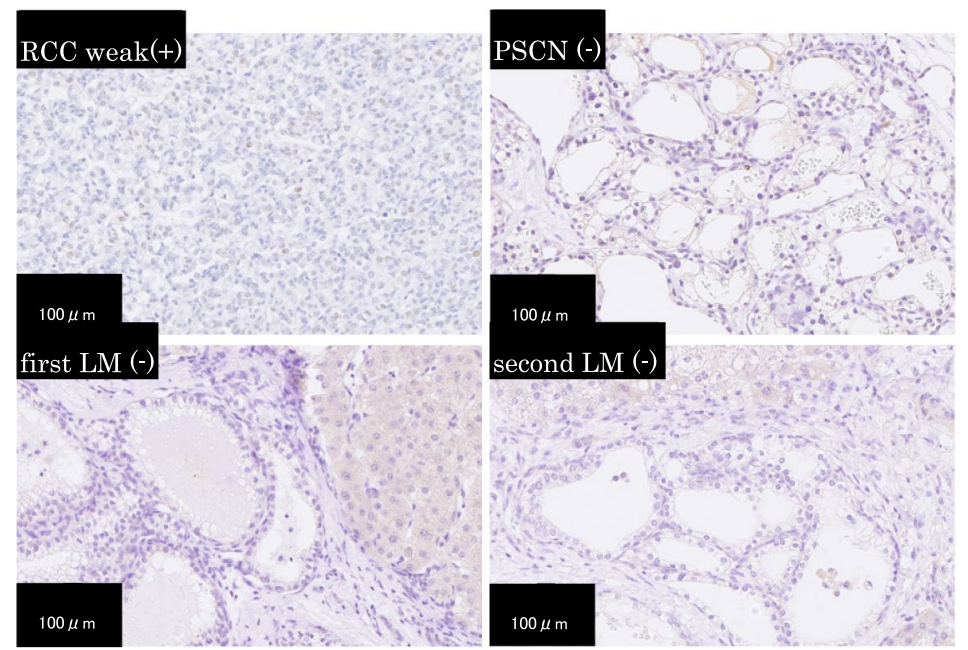

Fig. 2 continued

of glycogen that were stained by periodic acid Schiff with abolishment by diastase. Furthermore, immunohistochemically, the tumor was positive for pan-cytokeratin (AE1/AE3), epithelial membrane antigen (EMA), cytokeratin (CK) 7, CK18, CK19, epidermal growth factor receptor (EGFR), inhibin $\alpha$, laminin, type IV collagen, neuron specific enolase (NSE), and mucin (MUC) 6, but negative for CK20, CA125, S-100, CD10, CA19-9, pairedbox gene (PAX) 8, vimentin, CD56, MUC1, MUC2, and MUC5AC. These immunohistochemical findings were similar to those of the primary pancreatic SCN, but differed from the RCC resected previously (Fig. 2). Thus, the tumors were pathologically diagnosed as liver metastases of the pancreatic SCN, synonymous with serous cystadenocarcinoma in the World Health Organization (WHO) Classification of Tumours of the pancreas [9].

After the second surgery, the patient had follow-up examinations performed every 6 months again. At the first follow-up examination, one and two tumors located in the liver segment III and VIII, respectively, were detected by contrast-enhanced CT and Gd-EOB-DTPAenhanced MRI (Fig. 3). Compared to the contrastenhanced CT scan, the Gd-EOB-DTPA-enhanced MRI more clearly showed the tumors of segment VIII (Fig. 3a, c), as in the previous examination. On the other hand, the tumor of segment III was clearly detected by the contrast-enhanced CT, though undetectable in the GdEOB-DTPA-enhanced MRI (Fig. 3b, d). Liver metastases 

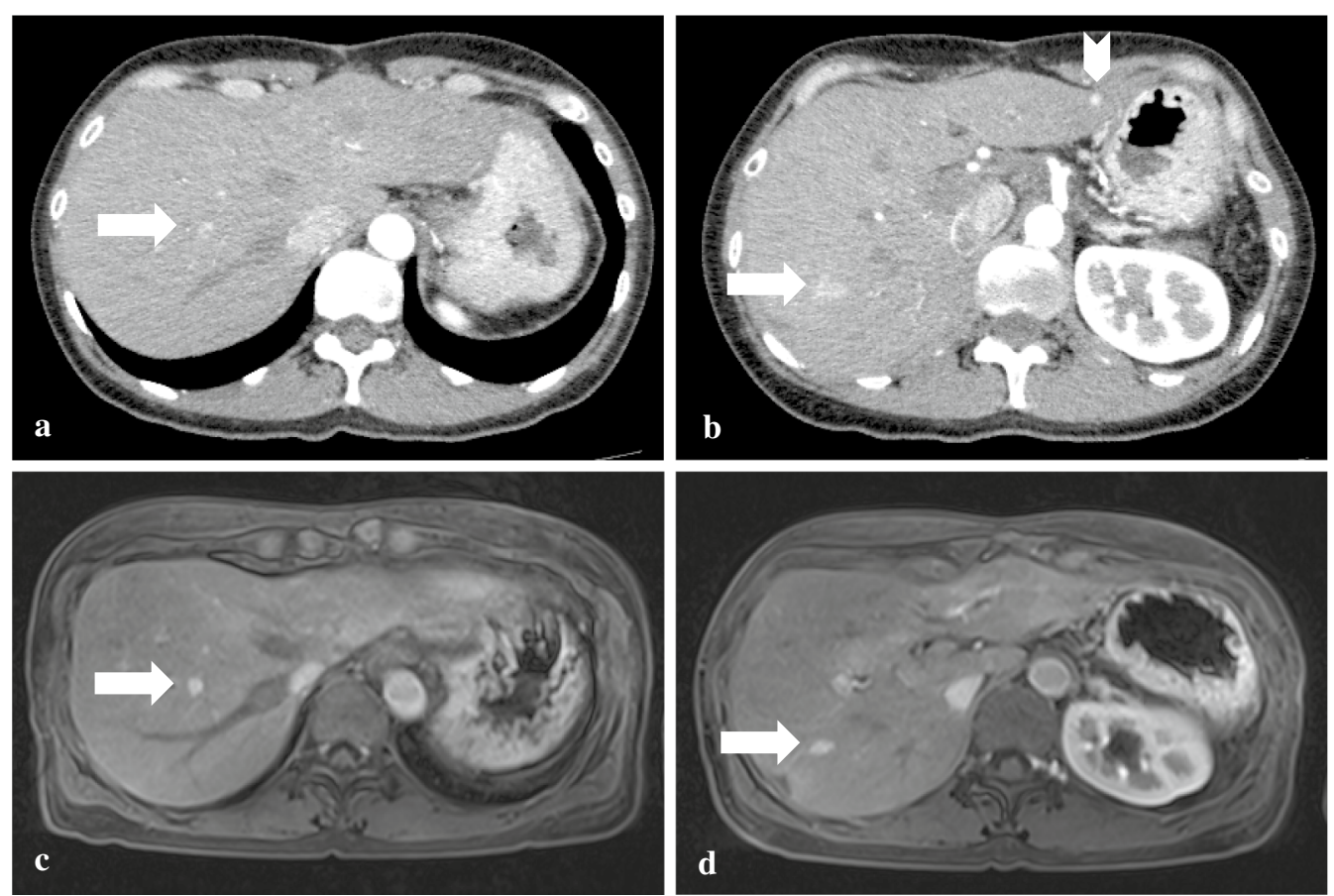

Fig. 3 a, b Contrast-enhanced CT scan. Post-arterially hyper-enhanced lesions were revealed in the liver segment VIII (a, arrow), segment III (b, arrowhead), and VIII (b, arrow). c, d Gd-EOB-DTPA-enhanced MRI. Two arterially hyper-enhanced lesions were revealed in liver segment VIII (c and d, arrow). The lesion of segment III detected by the CT scan was undetectable. CT computed tomography, Gd-EOB-DTPA gadolinium ethoxybenzyl diethylenetriamine penta-acetic acid, MRI magnetic resonance imaging

of SCN were radiologically suspected. Since it was a short period since the hepatectomy, radiological follow-up examinations were additionally performed every three months to observe changes in the number and size of the tumors. No increase in the number of the tumors was seen in the radiological examinations after 6 months. Thus, the liver tumors were considered to have a surgical indication. Anterior segmentectomy and partial resection of segment III were performed 66 months after the initial surgery and 13 months after the second, respectively. Findings of CE-IOUS using Sonazoid and intraoperative ICG fluorography were similar to those in the second surgery. Pathologically, the resected tumors again showed morphological and immunohistochemical features similar to the primary pancreatic SCN, hence these tumors were pathologically diagnosed as multiple metachronous liver metastases of pancreatic SCN, synonymous with serous cystadenocarcinoma (Fig. 2). Although the radiological findings of CT/MRI in the tumor of segment III were different from those in the tumors of segment VIII, no histopathological findings suggesting a difference in the radiological findings were observed.

Since then, radiological follow-up examinations have been continuously performed. The patient has remained disease-free without any recurrence after the third operation for 6.5 years until the recent last follow-up.

\section{Discussion}

To the best of our knowledge, we presented the first case of liver metastases of VHL-associated SCN. In addition, this case had a long-term fair prognosis without any recurrence after two hepatectomies for multiple metachronous liver metastases. Points mainly discussed in the clinical course of this case includes: (1) the clinical features of the distant metastasis of SCN; (2) treatment methods and prognosis regarding metastatic SCN, and (3) follow-up for SCN including VHL-associated SCN.

Metastasis of SCN is extremely rare. According to the current WHO classification, serous neoplasms of the pancreas are classified into serous cystadenoma and serous cystadenocarcinoma, in which "the diagnosis of malignancy in pancreatic serous neoplasms is restricted to cases with unequivocal distant metastasis beyond the pancreatic/peripancreatic bed." It was also described that $<20$ cases of serous cystadenocarcinoma have been reported when strict criteria requiring the presence of true distant metastases are used. 
Table 1 Characteristics of serous cystadenocarcinoma of the pancreas

\begin{tabular}{|c|c|c|c|c|c|c|c|c|c|}
\hline Case & Author & Year & Age/sex & Size $(\mathrm{cm})$ & $\begin{array}{l}\text { Signs or } \\
\text { symptoms }\end{array}$ & $\begin{array}{l}\text { Metastases } \\
\text { (single/ } \\
\text { multiple liver } \\
\text { metastases) }\end{array}$ & $\begin{array}{l}\text { Synchronous/ } \\
\text { metachronous } \\
\text { (time interval } \\
\text { from initial } \\
\text { treatment) }\end{array}$ & $\begin{array}{l}\text { Treatment for } \\
\text { metastases }\end{array}$ & $\begin{array}{l}\text { Outcome (time } \\
\text { after diagnosis of } \\
\text { metastases) }\end{array}$ \\
\hline 1 & George et al. [2] & 1989 & $70 / \mathrm{M}$ & 11 & $\begin{array}{l}\text { Hemorrhage from } \\
\text { gastric varices }\end{array}$ & Liver (multiple) & Synchronous & None & $\begin{array}{c}\text { Intraoperative death } \\
\text { due to blood loss }\end{array}$ \\
\hline 2 & $\begin{array}{l}\text { Friedman et al. } \\
\text { [13] }\end{array}$ & 1990 & $74 / F$ & 19 & $\begin{array}{l}\text { Right flank pain, } \\
\text { weight loss, } \\
\text { abdominal mass }\end{array}$ & $\begin{array}{l}\text { Liver (multiple), } \\
\text { lung, bone, } \\
\text { adrenal glands }\end{array}$ & Synchronous & None & $\begin{array}{l}\text { Dead of primary } \\
\text { disease }\end{array}$ \\
\hline 3 & Okada et al. [14] & 1991 & $63 / F$ & 12 & Abdominal pain & Liver (multiple) & $\begin{array}{l}\text { Metachronous } \\
\text { (4 years) }\end{array}$ & $\begin{array}{l}\text { Partial hepatec- } \\
\text { tomy }\end{array}$ & $\begin{array}{l}\text { Alive (NR) } \\
\text { (1 year) }\end{array}$ \\
\hline 4 & Yoshimi et al. [15] & 1992 & $63 / F$ & 12 & $\begin{array}{c}\text { abdominal mass, } \\
\text { epigastric pain }\end{array}$ & Liver (multiple) & $\begin{array}{l}\text { Metachronous } \\
\text { (3 years) }\end{array}$ & $\begin{array}{l}\text { Partial hepatec- } \\
\text { tomy }\end{array}$ & $\begin{array}{l}\text { Alive (NR) } \\
\text { (3 years) }\end{array}$ \\
\hline 5 & Ishikawa et al. [16] & 1998 & $63 / F$ & 12 & Abdominal pain & Liver (single) & $\begin{array}{l}\text { Metachronous } \\
\text { (3 years) }\end{array}$ & $\begin{array}{l}\text { Partial hepatec- } \\
\text { tomy }\end{array}$ & Not described \\
\hline 6 & Eriguchi et al. [17] & 1998 & $56 / F$ & 16 & Abdominal mass & Liver (multiple) & Synchronous & MCN & $\begin{array}{l}\text { Liver recurrence } \\
9 \text { years after MCN } \\
\text { Alive (NR) } 1 \text { year } \\
\text { after hepatectomy } \\
\text { and repeated } \\
\text { MCN for liver } \\
\text { recurrence } \\
\text { (10 years after } \\
\text { initial metastasis) }\end{array}$ \\
\hline 7 & Wu et al. [18] & 1999 & $57 / F$ & No data & Incidental finding & $\begin{array}{l}\text { Liver, (multiple) } \\
\text { peritoneum }\end{array}$ & $\begin{array}{l}\text { Metachronous } \\
\text { (10 years) }\end{array}$ & None & Not described \\
\hline 8 & Strobel et al. [19] & 2003 & $56 / F$ & 14 & $\begin{array}{l}\text { Abdominal pain, } \\
\text { diarrhea, weight } \\
\text { loss }\end{array}$ & $\begin{array}{l}\text { Liver } \\
\text { (single) }\end{array}$ & $\begin{array}{l}\text { Metachronous } \\
\text { (3 years) }\end{array}$ & $\begin{array}{l}\text { Partial hepatec- } \\
\text { tomy }\end{array}$ & $\begin{array}{l}\text { Alive }(\mathrm{NR}) \\
\text { (3 years) }\end{array}$ \\
\hline 9 & Franko et al. [20] & 2008 & $68 / F$ & 5 & $\begin{array}{l}\text { Hemorrhage from } \\
\text { gastric varices, } \\
\text { abdominal pain, } \\
\text { weight loss }\end{array}$ & Liver (multiple) & $\begin{array}{l}\text { Metachronous } \\
\text { (3 years) }\end{array}$ & None & $\begin{array}{l}\text { Dead of primary } \\
\text { disease } \\
\text { (9 months) }\end{array}$ \\
\hline 10 & Bano et al. [21] & 2011 & $62 / M$ & 7 & $\begin{array}{l}\text { Abdominal pain, } \\
\text { vomiting, } \\
\text { weight loss }\end{array}$ & Liver (multiple) & $\begin{array}{l}\text { Metachronous } \\
\text { (1 year) }\end{array}$ & $\mathrm{MCN}$ & $\begin{array}{l}\text { Alive (NR) } \\
\text { (1 year) }\end{array}$ \\
\hline 11 & Bramis et al. [22] & 2012 & $86 / F$ & 17 & Abdominal pain & Liver (multiple) & Synchronous & None & $\begin{array}{l}\text { Dead of unrelated } \\
\text { disease (1 month) }\end{array}$ \\
\hline 12 & Wasel et al. [23] & 2013 & $68 / M$ & 12 & Incidental finding & Liver (multiple) & Synchronous & $\begin{array}{l}4 \text { months of } \\
\text { chemotherapy }\end{array}$ & Alive (1 year) \\
\hline 13 & Kainuma et al. [24] & 2015 & $69 / M$ & 6 & $\begin{array}{l}\text { Abdominal } \\
\text { discomfort }\end{array}$ & Liver (multiple) & Synchronous & $\begin{array}{l}\text { Partial hepatec- } \\
\text { tomy }\end{array}$ & $\begin{array}{l}\text { Alive }(\mathrm{NR}) \\
\text { ( } 2.5 \text { years) }\end{array}$ \\
\hline 14 & Huh et al. [25] & 2016 & $52 / F$ & 9 & Abdominal mass & Liver (multiple) & $\begin{array}{l}\text { Metachronous } \\
\text { (5 years) }\end{array}$ & None & $\begin{array}{l}\text { Alive } \\
\text { (1.5 years) }\end{array}$ \\
\hline 15 & $\begin{array}{l}\text { Van Dyke et al. } \\
\text { [26] }\end{array}$ & 2016 & $78 / \mathrm{M}$ & 16 & Incidental finding & Liver (multiple) & Synchronous & RFA & $\begin{array}{l}\text { MCN for liver recur- } \\
\text { rence } 4.5 \text { years } \\
\text { after RFA } \\
\text { Alive observing } \\
\text { liver recurrence } \\
15 \text { months after } \\
\text { MCN (6 years after } \\
\text { initial metastasis) }\end{array}$ \\
\hline 16 & Massaras et al. [27] & 2020 & $60 / F$ & 9 & Incidental finding & $\begin{array}{l}\text { Liver } \\
\text { (single) }\end{array}$ & Synchronous & $\begin{array}{l}\text { Sunitinib (4 } \\
\text { cycles), partial } \\
\text { hepatectomy }\end{array}$ & $\begin{array}{l}\text { Alive (NR) } \\
\text { (3 years) }\end{array}$ \\
\hline
\end{tabular}


Consistent with this description, when we conducted a literature review of pancreatic serous cystadenocarcinoma using PubMed search using the keywords "pancreas" and "serous cystadenocarcinoma", we found 16 cases of pancreatic serous cystadenocarcinoma, as reviewed in Table 1 . There have been no reports of metastatic SCN associated with VHL. Regarding metastasis, liver metastases were found in all patients. Multiple liver metastases were observed in $81 \%(13 / 16)$ of the reviewed cases. There were two cases with metastases in multiple organs: one case revealed metastases to the liver, lung, bone and adrenal glands, and the other case revealed liver metastasis and peritoneal dissemination. Synchronous metastases were seen in $50 \%$ of the reviewed cases, and the remaining $50 \%$ were metachronous metastasis. With respect to the treatment and the prognosis for metastatic SCNs, all of reported three cases with single liver metastasis underwent surgical resection, and one of them was alive without recurrence 3 years after surgery, although the long-term prognosis of the remaining two cases was unknown. Multiple liver metastases were reported in 13 cases. Three cases underwent radical resection, and were alive without recurrence 1-3 years after surgery. Locoregional therapy, microwave coagulo-necrotic therapy ( $\mathrm{MCN}$ ) or radiofrequency ablation (RFA), was performed in three cases, in one of which the patient was alive with no recurrence one year after MCN. The remaining two cases had liver recurrences. The case that underwent MCN for initial liver metastases received partial resection and repeated $\mathrm{MCN}$ for new liver metastases after 9 years, and has been alive without any recurrences one year after the second surgery. On the other hand, the case that underwent RFA for initial liver metastases received $\mathrm{MCN}$ for new liver metastases after 4.5 years, had multiple liver metastases again 15 months after second surgery, and has been alive 6 years after the initial metastasis with liver metastases observed because of old age. Although these two cases were treated with systemic chemotherapy, one showed no change in the metastatic tumors, and another treated with sunitinib had unknown efficacy for the metastatic tumors. Including our case, metastasectomy or locoregional therapy is suggested to have favorable efficacy for liver metastases of pancreatic SCN.

The time interval between detection of pancreatic $\mathrm{SCN}$ and that of metachronous metastases was from 1 to 10 years. Similar to our case, $75 \%$ (6/8) of metachronous metastatic cases were burdened with distant metastases 3-5 years after the detection of pancreatic $\mathrm{SCN}$. Interestingly, late metastatic relapses due to a relatively indolent course were detected 9 and 10 years after the initial treatment. Therefore, although there are concerns about the cost-benefit performance and radiological exposure due to radiological examination, the long-term and continuing follow-up might be needed after the treatment of pancreatic SCN. In addition, in cases of VHL-associated SCN, we should be careful about the onset of other neoplastic diseases, such as hemangioblastoma of central nervous system, RCC and pheochromocytoma [10-12].

Interestingly, the histopathological findings of our case showed that the metastatic tumors in the liver were localized in portal regions, and revealed no proliferation or infiltration into the liver parenchyma. No similar findings have been reported in cases with liver metastases of SCN. Further accumulation of similar cases is needed to investigate whether this is characteristic histopathological findings of liver metastases of pancreatic SCN associated with VHL disease.

\section{Conclusion}

In summary, a long-term survivor of metachronous liver metastases of pancreatic SCN associated with VHL disease was presented. This is the first report of metastatic SCN associated with VHL. A long-term follow-up may be needed for SCN. Surgical resection might confer a favorable prognosis in cases with liver metastases of pancreatic SCN.

\section{Abbreviations \\ SCN: Serous cystic neoplasm; VHL: Von Hippel-Lindau disease; CT: Com- puted tomography; RCC: Renal cell carcinoma; Gd-EOB-DTPA: Gadolinium ethoxybenzyl diethylenetriamine penta-acetic acid; MRI: Magnetic resonance imaging; CE-IOUS: Contrast-enhanced intraoperative ultrasonography; ICG: Indocyanine green; EMA: Epithelial membrane antigen; CK: Cytokeratin; EGFR: Epidermal growth factor receptor; NSE: Neuron-specific enolase; MUC: Mucin; CD: Cluster of differentiation; PAX: Paired-box gene; WHO: World Health Organization; MCN: Microwave coagulo-necrotic therapy; RFA: Radiofrequency ablation.}

\section{Acknowledgements}

We thank all the surgeons, gastroenterologists, radiologists, and pathologists who performed examinations and treatments for the patient.

\section{Authors' contributions}

TK and MM wrote the paper. KH and TF performed histopathological evaluation. HK, MI, HO, KN, TM, TK, AM, TF and MU reviewed the manuscript, and revised it critically for important intellectual content. All authors read and approved the final manuscript.

\section{Funding}

Michiaki Unno: Management Expenses Grants from the Government of Japan to national university corporations supplied every fiscal year.

\section{Availability of data and materials}

The datasets supporting the conclusions of this article are included within the article.

\section{Declarations}

Ethics approval and consent to participate Not applicable. 


\section{Consent for publication}

Written informed consent for publication was obtained from the patient.

\section{Competing interests}

The authors declare that they have no competing interests.

\section{Author details}

'Department of Surgery, Tohoku University Graduate School of Medicine, 1-1 Seiryomachi, Aobaku, Sendai 980-8574, Japan. ${ }^{2}$ Department of Investigative Pathology, Tohoku University Graduate School of Medicine, 1-1 Seiryomachi, Aobaku, Sendai 980-8574, Japan. ${ }^{3}$ Division of Gastroenterology, Tohoku University Graduate School of Medicine, 1-1 Seiryomachi, Aobaku, Sendai 980-8574, Japan.

Received: 22 May 2021 Accepted: 18 June 2021

Published online: 30 June 2021

\section{References}

1. Kosmahl M, Wagner J, Peters K, Sipos B, Kloppel G. Serous cystic neoplasms of the pancreas: an immunohistochemical analysis revealing alpha-inhibin, neuron-specific enolase, and MUC6 as new markers. Am J Surg Pathol. 2004:28:339-46.

2. George DH, Murphy F, Michalski R, Ulmer BG. Serous cystadenocarcinoma of the pancreas: a new entity? Am J Surg Pathol. 1989;13:61-6.

3. Wu W, Li J, Pu N, Li G, Wang X, Zhao G, et al. Surveillance and management for serous cystic neoplasms of the pancreas based on total hazards-a multicenter retrospective study from China. Ann Transl Med. 2019;7:807.

4. Latif F, Tory K, Gnarra J, Yao M, Duh FM, Orcutt ML, et al. Identification of the von Hippel-Lindau disease tumor suppressor gene. Science. 1993;260:1317-20

5. Lonser RR, Glenn GM, Walther M, Chew EY, Libutti SK, Linehan WM, et al. von Hippel-Lindau disease. Lancet. 2003;361:2059-67.

6. Hammel PR, Vilgrain V, Terris B, Penfornis A, Sauvanet A, Correas JM, et al. Pancreatic involvement in von Hippel-Lindau disease. The Groupe Francophone d'Etude de la Maladie de von Hippel-Lindau. Gastroenterology. 2000;119:1087-95.

7. Charlesworth M, Verbeke CS, Falk GA, Walsh M, Smith AM, Morris-Stiff G. Pancreatic lesions in von Hippel-Lindau disease? A systematic review and meta-synthesis of the literature. J Gastrointest Surg. 2012;16:1422-8.

8. Kanno A, Satoh K, Hamada S, Hirota M, Masamune A, Motoi F, et al. Serous cystic neoplasms of the whole pancreas in a patient with von Hippel-Lindau disease. Intern Med. 2011:50:1293-8.

9. Singhi AD, Adsay NV, Hiraoka N, Terris B. Serous neoplasms of the pancreas. In:WHO Classification of Tumours Editorial Board. World Health Organization Classification of Tumours. Digestive System Tumours (5th ed). Lyon: International Agency for Research on Cancer; 2019. pp. 303-306.

10. Lamiell JM, Salazar FG, Hsia YE. von Hippel-Lindau disease affecting 43 members of a single kindred. Medicine (Baltimore). 1989;68:1-29.

11. Maher ER, Yates JR, Harries R, Benjamin C, Harris R, Moore AT, et al. Clinical features and natural history of von Hippel-Lindau disease. Q J Med. 1990:77:1151-63.
12. Maddock IR, Moran A, Maher ER, Teare MD, Norman A, Payne SJ, et al. A genetic register for von Hippel-Lindau disease. J Med Genet. 1996;33:120-7.

13. Friedman HD. Nonmucinous, glycogen-poor cystadenocarcinoma of the pancreas. Arch Pathol Lab Med. 1990;114:888-91.

14. Okada T, Nonami T, Miwa T, Yamada F, Ando K, Tatematsu A, et al. Hepatic metastasis of serous cystadenocarcinoma resected 4 years after operation of primary tumors - a case report. Nihon Shokakibyo Gakkai zasshi Jpn J Gastro-enterol. 1991;88:2719-23.

15. Yoshimi N, Sugie S, Tanaka T, Aijin W, Bunai Y, Tatematsu A, et al. A rare case of serous cystadenocarcinoma of the pancreas. Cancer. 1992;69:2449-53.

16. Ishikawa T, Nakao A, Nomoto S, Hosono J, Harada A, Nonami T, et al. Immunohistochemical and molecular biological studies of serous cystadenoma of the pancreas. Pancreas. 1998;16:40-4.

17. Eriguchi N, Aoyagi S, Nakayama T, Hara M, Miyazaki T, Kutami R, et al. Serous cystadenocarcinoma of the pancreas with liver metastases. J Hepatobiliary Pancreat Surg. 1998:5:467-70.

18. Wu CM, Fishman EK, Hruban RK, Schlott WD, Cameron JL. Serous cystic neoplasm involving the pancreas and liver: an unusual clinical entity. Abdom Imaging. 1999;24:75-7

19. Strobel O, Z'Graggen K, Schmitz-Winnenthal FH, Friess H, Kappeler A Zimmermann A, et al. Risk of malignancy in serous cystic neoplasms of the pancreas. Digestion. 2003;68:24-33.

20. Franko J, Cole K, Pezzi CM, Montone KT, Redmond J. Serous cystadenocarcinoma of the pancreas with metachronous hepatic metastasis. Am J Clin Oncol. 2008;31:624-5.

21. Bano S, Upreti L, Puri SK, Chaudhary V, Sakuja P. Imaging of pancreatic serous cystadenocarcinoma. Jpn J Radiol. 2011;29:730-4.

22. Bramis K, Petrou A, Papalambros A, Manzelli A, Mantonakis E, Brennan N, et al. Serous cystadenocarcinoma of the pancreas: report of a case and management reflections. World J Surg Oncol. 2012;10:51.

23. Wasel BA, Keough V, Huang WY, Molinari M. Histological percutaneous diagnosis of stage IV microcystic serous cystadenocarcinoma of the pancreas. BMJ Case Rep. 2013. https://doi.org/10.1136/bcr-2012-007924.

24. Kainuma $\mathrm{O}$, Yamamoto $\mathrm{H}$, Cho A, Arimitsu H, Yanagibashi H, Takiguchi N, et al. Solid variant type of serous cystadenocarcinoma of the pancreas: a case report and review of the literature. Pancreatology. 2015;15:197-9.

25. Huh J, Byun JH, Hong SM, Kim KW, Kim JH, Lee SS, et al. Malignant pancreatic serous cystic neoplasms: systematic review with a new case. BMC Gastroenterol. 2016;16:97.

26. Van Dyke TJ, Johlin FC, Bellizzi AM, Howe JR. Serous cystadenocarcinoma of the pancreas: clinical features and management of a rare tumor. Dig Surg. 2016:33:240-8.

27. Massaras D, Pantiora EV, Koutalas J, Primetis EC, Fragulidis GP. Serous microcystic cystadenocarcinoma of the pancreas with synchronous liver metastases: clinical characteristics and management. Cureus. 2020;12:e7707.

\section{Publisher's Note}

Springer Nature remains neutral with regard to jurisdictional claims in published maps and institutional affiliations.

\section{Submit your manuscript to a SpringerOpen ${ }^{\circ}$ journal and benefit from:}

- Convenient online submission

- Rigorous peer review

- Open access: articles freely available online

- High visibility within the field

Retaining the copyright to your article

Submit your next manuscript at springeropen.com 